\title{
Żaneta Oczkowska
}

\section{Neutralność państwa}

\author{
DOI: $10.35757 /$ CIV.2007.10.09
}

Gdy zastanawiamy się nad pojęciem państwa, nasuwają się między innymi następujące sformułowania - polityczna organizacja społeczeństwa, $\mathrm{z}$ suwerenną władza, wyposażona $\mathrm{w}$ organy przymusu. Definicja państwa jest nieodłącznie związana $z$ jego funkcjami, a te są dość zróżnicowane.

Każde $z$ wyżej wymienionych określeń - a nie jest to wyliczenie wyczerpujace - budzi wiele watpliwości. Nabierają one coraz to nowych kontekstów zwłaszcza w świecie globalnej unifikacji, a także w związu z rosnącymi zagrożeniami, choćby terroryzmem.

Chciałabym poświęcić swój artykuł jedynie wąskiemu wycinkowi problematyki definicyjnej państwa - mianowicie kwestii relacji władzy i jednostki w nowoczesnym państwie, a konkretnie zagadnieniu neutralności państwa (czy neutralność jest możliwa, czy jest wskazana i co w ogóle oznacza). Ponieważ w głównym nurcie myśli politycznej od dawna ścieraja się ze sobą dwie koncepcje dotyczace zakresu ingerencji państwa w życie jednostki - koncepcja minimalistyczna i koncepcja tak zwanego dobra wspólnego - wydaje mi się, że warto się zastanowić nad pojęciem „neutralność", przeanalizować, co ono ze soba niesie, a także jakie konsekwencje wynikaja $z$ tego dla poszczególnych jednostek oraz jakich zagrożeń dopatrują się przeciwnicy wizji państwa neutralnego.

Spór między zwolennikami i przeciwnikami neutralności państwa $z$ pewnością nie ma charakteru czysto teoretycznego. Dotyczy

Żaneta Oczkowska - absolwentka wydziałôw prawa i filozofii Uniwersytetu Jagiellońskiego, doktorantka (praca Rola podmiotowości w liberalizmie i komunitaryzmie), współpracuje ze Społecznym Instytutem Wydawniczym Znak. 
zarówno polityków, jak i całego społeczeństwa. Brak zgody w tej kwestii często stanowi podstawę konfliktów (czego egzemplifikacja może być choćby polska scena polityczna ${ }^{1}$ ) związanych na przykład $z$ problemem aborcji czy eutanazji.

Neutralność jest niewątpliwie jedna $z$ głównych cech definiujacych nowoczesne państwo liberalne. W ujęciu niektórych liberałów, jak choćby na gruncie polskim u Wojciecha Sadurskiego ${ }^{2}$, najważniejszymi wartościami definiującymi państwo demokratyczno-liberalne sa nie tyle wolność i własność, ile tolerancja i kompromis (czyli neutralność państwa, rozdzielenie sfery prawa państwa od moralności i tym samym stworzenie obszaru do dyskusji, polemiki, sporu - co jest nieuniknione w tak zorganizowanej przestrzeni - przede wszystkim zaś oddzielenie sfery moralności od przymusu państwowego).

Problem zaangażowania państwa budzi kontrowersje nie tyle w sferze ekonomicznej (choć i tu ścierają się różne koncepcje), ile głównie w sferze moralnej czy też - ogólnie rzecz ujmujacc - w sferze światopoglądowej.

„Liberalizm to zasada prawa politycznego, według którego władza publiczna, mimo swej potęgi, sama sobie narzuca ograniczenia, tak aby nawet kosztem tej władzy zostawić w rządzonym przez siebie państwie miejsce do życia dla wszystkich tych, którzy nie myśla ani nie czuja tak jak ona, czyli tak jak silniejsi, jak większość. Liberalizm - należy to dziś przypomnieć - jest najwyższą formą wspaniałomyślności, jest prawem, które większość nadaje mniejszościom i jako takie jest najszlachetniejszym wołaniem, jakie rozległo się na ziemi od zarania jej dziejów. Proklamuje wolę współżycia $z$ wrogiem, a co więcej, $z$ wrogiem słabszym od siebie”3.

\footnotetext{
1 Nie jest to bynajmniej jednak przypadłość tylko naszego kraju, taki podział można dostrzec zarówno w krajach europejskich, jak i w Stanach Zjednoczonych, gdzie zresztą spór ten, przynajmniej w wymiarze teoretycznym, w pewnym sensie został zapoczątkowany we współczesnej myśli politycznej.

2 W. Sadurski: Liberałów nikt nie kocha. Eseje i publicystyka 1996-2002, Prószyński i S-ka, Warszawa 2003.

3 J. Ortega y Gasset: Bunt mas $i$ inne pisma socjologiczne, przekład P. Niklewicz, H. Woźniakowski, Państwowe Wydawnictwo Naukowe, Warszawa 1982, s. 86.
} 
Taką apologię liberalizmu głosił José Ortega y Gasset - liberalizmu nowoczesnego, $z$ jego etyką indywidualizmu, różnorodnościa form życia $\mathrm{w}$ społeczeństwie. $\mathrm{W}$ takim rozumieniu liberalizmu państwo - a, co za tym idzie, porządek polityczny - ma za zadanie respektować i chronić pluralizm rozmaitych tradycji, pozwalajac na ich pokojowa rywalizację. W liberalnym dyskursie nieuchronnie pojawia się pytanie o postawę moralna państwa w kontekście wyżej opisanych jego zadań, a zarazem wolności jednostki. Część liberałów opowiada się w tym względzie za ideałem neutralności państwa w sferze moralno-obyczajowej. Według nich państwo nie ma być „narzędziem umoralniania społeczeństwa, lecz tylko bezstronnym arbitrem, którego zadaniem jest współistnienie wyznawców różnych moralności i światopoglądów - jeśli tylko swoim postępowaniem nikomu nie wadza" ${ }^{4}$. Czy neutralność państwa - nie tylko w teorii, ale także w praktyce - jest w ogóle możliwa i jak należy ja rozumieć - co do tego nie ma zgodności nawet wśród samych liberałów. Zapewne jest ideałem pożądanym przez znaczna ich część, $z$ drugiej zaś strony jest krytykowana zarówno przez liberałów zorientowanych bardziej konserwatywnie, jak i przez przedstawicieli nurtów antyliberalnych.

Ponieważ w kwestii idei neutralności rysuja się dwa podstawowe problemy - a mianowicie problem rozumienia neutralności oraz problem zasadności tej idei - postaram się w takiej kolejności prześledzić wątki $z$ tym związane.

Gdy mówimy o neutralności państwa, przede wszystkim nasuwa się problem tolerancji religijnej i związanej $z$ tym kwestii relacji między Kościołem a państwem. Współcześnie pojmowanie tego zagadnienia jest nieco zawężone, gdyż mówiąc o neutralności, mamy najczęściej na myśli dystansowanie się państwa wobec jakichkolwiek koncepcji życia (niekiedy pojawia się sformułowanie dobrego życia), niekoniecznie mających źródła religijne. Niewątpliwie jednak to właśnie zagadnienie tolerancji religijnej $\mathrm{w}$ dużym

4 W. Sadurski: Racje liberała, Presspublica, Warszawa 1992, s. 14. 
stopniu przyczyniło się do dzisiejszych dyskusji nad modelem państwa neutralnego, a neutralność państwa jest poszerzeniem roli neutralności religijnej.

Idea państwa oddzielonego od sfery życia religijnego narodziła się $\mathrm{w}$ XVII wieku wraz $\mathrm{z}$ narastaniem ruchów reformatorskich $\mathrm{w}$ dotychczas jednolitej religijnie Europie Zachodniej. Ideał neutralności religijnej często był powodowany względami praktycznymi, a mianowicie dążeniem do zachowania bezpieczeństwa i pokoju $\mathrm{w}$ społeczeństwach o zróżnicowanych poglądach religijnych. Jednym $z$ piewców tolerancji religijnej był John Locke. W Liście o tolerancji przedstawił on klasyczna argumentację na rzecz tolerancji religijnej. Powoływał się w nim na konieczność oddzielenia kwestii sakralnych od zagadnień świeckich oraz ograniczenia władzy politycznej do pewnych wąsko zakreślonych interesów obywatelskich: bezpieczeństwa i własności jednostek, czyli, jak to rozumiał, raczej dóbr materialnych niż duchowych. Locke, podobnie jak nowożytny liberał Karl Popper, zwracał również uwagę na zawodność sądów religijnych oraz na to, jak ważne jest korygowanie tych poglądów w wyniku pokojowej dyskusji publicznej. Problemem wydaje się tutaj konieczność takiej interpretacji swojej religii przez każdego $z$ wyznawców, aby dała się ona pogodzić $z$ innymi współistniejącymi religiami. Locke, niejako przewidując tę kwestię, stwierdza, iż uważa tolerancję za probierz prawdziwego kościoła, odwołując się w ten sposób także do sumień prześladowców (religijnych).

Nieco inaczej bronił tolerancji John Stuart Mill, który cenił wolność i różnorodność, gdyż uważał, iż prowokują one do eksperymentowania, krytycyzmu i debaty publicznej, a to $z$ kolei przyczynia się do wzrostu ludzkiego szczęścia i właściwie rozumianego postępu. W podobny sposób współcześnie bronił autonomicznego liberalizmu Joseph Raz ${ }^{5}$. Oczywiście, spotkało się to $z$ wieloma zarzutami, iż autonomia to nazbyt stronniczy ideał życia, może on bowiem powodować, że rację bytu będa miały jedynie te koncepcje, które same cenia autonomię.

5 J. Raz: Morality of Freedom, Clarendon Press, Oxford 1986. 
Aby uniknąć tej stronniczości, podkreśla się, że państwo powinno dążyć raczej do ideału neutralności. W dalszej części postaram się pokazać, iż niekoniecznie uda się w ten sposób uniknać wyżej wymienionego zarzutu, który jest stawiany idei neutralności przez zwolenników państwa zaangażowanego moralnie.

Jak już wcześniej wspomniałam, neutralność jest pojęciem dość mglistym i chcac doprecyzować jego znaczenie, trudno szukać u liberałów jednolitej koncepcji. Dużo miejsca tym zagadnieniom poświęca Charles E. Larmore w książce Patterns of Moral Complexity. Przeprowadza tam rozróżnienie na neutralność proceduralną oraz neutralność celu. Przy czym sam opowiada się za pierwsza koncepcją, natomiast John Rawls w Liberalizmie politycznym, podążając za rozróżnieniem Larmore'a, za właściwe uznaje rozumienie neutralności w sposób celowościowy (jedynie taka bowiem wydaje mu się zgodna $z$ jego koncepcja sprawiedliwości jako bezstronności) ${ }^{6}$.

Tym, co zdaniem Larmore'a jest cecha charakterystyczna politycznego liberalizmu, a jednocześnie wyróżnia go na tle innych koncepcji, jest idea neutralności państwa. Podobnie jak wspomniany wcześniej Wojciech Sadurski uważa on, że nie wolność, nie podział na sferę publiczną i prywatną, lecz właśnie neutralność stała się wyznacznikiem dla współczesnej myśli liberalnej . Neutralność państwa - czyli powstrzymanie się od wspierania jakiejkolwiek określonej koncepcji dobrego życia - stanowi odpowiedź na różne formy spełniania życia pozbawione hierarchicznego uporządkowania. Stąd już prosta droga do pluralizmu i rozumnej niezgody.

Nim przejdę do uzasadnienia tego punktu widzenia, postaram się wyjaśnić, czym jest neutralność dla Larmore'a.

Nieunikniony wydaje się fakt, iż pewne decyzje polityczne (może nawet wszystkie - nie jest jednak teraz istotne, czy możliwe sa de-

\footnotetext{
6 Nie sa to jedyni autorzy, którzy zajmuja się kwestią neutralności, wydaje się jednak, że to właśnie oni przedstawili koncepcje najbardziej reprezentatywne, a ponadto najbardziej spójne i przekonujace. W podobnych duchu jak Rawls na temat neutralności wypowiada się Ronald Dworkin; do idei dialogu nawiązuje też Bruce Ackerman.

7 Ch.E. Larmore: Patterns of Moral Complexity, Cambridge University Press, Cambridge 1987, s. 42 i nast. Oczywiście, nie znaczy to, iż wolność jest mniej ważna. Jednak szukając drogi jej realizacji, należy podążać za ideałem neutralności.
} 
cyzje polityczne o ambiwalentnych skutkach) przynoszą niektórym ludziom więcej korzyści niż pozostałym. Prowadzi to do sytuacji, w której pewne sposoby życia zostaja wzmocnione. Ale sam ten fakt, zdaniem Larmore'a, nie pozbawia państwa przymiotu neutralności. Neutralność bowiem, to nie wynik, ale procedura działania. I tak decyzja państwowa może być rozumiana jako neutralna, jeśli nie odwołuje się w żaden sposób do partykularnych koncepcji dobrego życia. W praktyce miałoby to polegać na ograniczeniu liczby czynników, na które wolno nam się powoływać w celu uzasadnienia decyzji politycznych. Neutralność rozumiana proceduralnie nie wyklucza, iż istnieja pewne zadania, które liberalne państwo powinno realizować, jednak pewne cele sa $z$ góry wykluczone (na przykład ustanowienie państwa wyznaniowego). Wszystkie zaś cele mające neutralne uzasadnienie moga być wspierane przez liberalne państwo. Zdaniem Larmore'a takimi właśnie celami sa nie tylko ochrona życia i własności (które są oczywiste). Państwo neutralne nie musi być, jak u Nozicka, jedynie „nocnym stróżem”. Larmore podkreśla, iż neutralność to ideał polityczny. Wynikaja $z$ tego dwie ważne konsekwencje.

Po pierwsze, to decyzje polityczne musza mieć neutralne uzasadnienie, inne instytucje nie musza działać w tym samym duchu neutralności. Można też uznać, iż zasada ta nie nadaje się do stosowania przez jednostki. Według Sadurskiego wymóg neutralnego zachowania względem innych brzmiałby nie tylko dziwacznie, ale i szkodliwie „właśnie dlatego, że ludzie nie sa neutralni względem rozmaitych kodeksów moralnych, państwo ma obowiązek zachować neutralność w społeczeństwie pluralistycznym"8.

Po drugie, jak przyznaje Larmore, neutralność to raczej pewien ideał, do którego państwo powinno dążyć, niż stan faktyczny.

Szukając uzasadnienia dla swojej koncepcji neutralności, a jednocześnie akceptując pluralizm i rozumną niezgodę, Larmore wyróżnia dwie grupy argumentów. Pierwsza grupa opiera się na opi-

\footnotetext{
8 W. Sadurski: Neutralność moralna prawa (przyczynek do teorii prawa liberalnego), „Państwo i Prawo" 1990, nr 7.
} 
nii, iż przekonania pewnych ludzi sa nie do zaakceptowania przez innych. Tu zaliczane zostaja argumenty: ze sceptycyzmu - brak podstaw do preferowania jednego stylu życia lub eliminowania innych; $z$ eksperymentu - najlepsza droga wyboru to wypróbowanie różnych koncepcji, a następnie porównanie ich i wybór najlepszej; $z$ indywidualnej autonomii - każdy ma swój styl życia.

Larmore odrzuca tę grupę argumentów i szuka uzasadnienia w uniwersalnej normie racjonalnego dialogu: „Kiedy dwoje ludzi nie zgadza się w jakiejś konkretnej kwestii, lecz chce kontynuować rozmowę o bardziej ogólnym problemie, który chcą rozwiązać, każdy $z$ nich powinien abstrahować od przekonań odrzucanych przez drugiego, aby formułować argumenty oparte na tych własnych przekonaniach, które przekonałyby drugiego o prawdziwości kwestionowanego sądu bądź przenieść rozmowę na inna płaszczyznę, na której możliwości porozumienia wydaja się większe" Oczywiście, nie prowadzi to do stwierdzenia, że życie społeczno-polityczne jest tylko rozmowa. Niemniej przedmiotem debaty publicznej nieustannie jest problem zasad wyznaczajacych podstawę współczesnego społeczeństwa. Zróżnicowane poglądy (niemożliwe do pogodzenia) będa w nieunikniony sposób prowadzić do sytuacji konfliktowych. Państwo liberalne musi jednak stale podejmować decyzje dotyczące różnych kwestii. Decyzje te zaś powinny znajdować neutralne uzasadnienie, respektując jednocześnie skonfliktowane poglądy. Zadaniem państwa jest więc prowadzenie wszelkich debat publicznych $z$ zastosowaniem wspomnianej wcześniej normy racjonalnego dialogu. Tak rozumiana neutralność państwa nie jest oczywiście neutralnościa całkowita, ale jedynie neutralnością w stosunku do sprzecznych koncepcji dobrego życia, a nie do wszystkich wartości i norm jako takich. Sama już wola posługiwania się norma racjonalnego dialogu $\mathrm{w}$ debacie publicznej w przypadku odmienności stanowisk nie jest stanowiskiem neutralnym, lecz zgodna jest $z$ zasadac rozwiazywania konfliktów

${ }_{9}$ Ch.E. Larmore: Patterns..., s. 53. 
na innej drodze niż przemoc. Ta wola jest jednak tym, co różni liberałów od fanatyków ${ }^{10}$.

Nieco inaczej uzasadnia ideę neutralności John Rawls. Jak wspomniałam, podąża on za rozróżnieniem Larmore'a na neutralność procedury i neutralność celu. We wcześniejszych pracach Rawls starał się unikać terminu „neutralność”, zdając sobie sprawę $z$ jego wieloznaczności, za właściwsze uznając sformułowanie „prymat słusznego nad dobrym”, choć nie wydaje się ono bardziej przejrzyste. Dopiero w Politycznym liberalizmie odwołuje się wprost do idei neutralności. Stara się tam precyzyjnie wyłożyć swoje stanowisko, co niejako miało być odpowiedzia na wcześniejsze zarzuty formułowane pod jego adresem. Niektórzy krytycy Rawlsa uznali bowiem, iż broni on w swojej koncepcji pierwszeństwa słuszności neutralności w sensie potocznym, polegającej na konieczności zagwarantowania wszystkim stylom życia równego udziału w życiu publicznym, przy czym owo gwarantowanie miałoby polegać na aktywnej roli państwa $\mathrm{w}$ tym względzie ${ }^{11}$. Taka neutralność byłaby całkiem nieliberalna, liberałowie akceptuja bowiem fakt, iż wolność i swobody obywatelskie prowadzą do niejednakowych konsekwencji dla poszczególnych jednostek.

Odnosząc rozróżnienie Larmore'a do swojej koncepcji sprawiedliwości jako bezstronności, Rawls stwierdza stanowczo, iż sprawiedliwość jako bezstronność nie jest proceduralnie neutralna, jakkolwiek by ową neutralność proceduralną rozumieć - czy jako brak odwołania do jakichkolwiek wartości (jeśli to w ogóle jest możliwe) bądź też przez odwołanie do wartości neutralnych.

„W oczywisty sposób jej (tj. sprawiedliwości jako bezstronności) zasady są materialne i wyrażają dużo więcej wartości niż tylko proceduralne [...]. Jako pewna koncepcja polityczna chce być ośrodkiem częściowego konsensusu. [...] Poszukuje wspólnej podstawy - czy, jeśli kto woli, neutralnej podstawy - gdy zachodzi fakt

Ibidem, s. 60

11 Por. np. J. Raz: Morality..., s. 117 
rozumnego pluralizmu. Ale tak zdefiniowana wspólna podstawa nie jest podstawa neutralna proceduralnie" ${ }^{12}$.

Przechodząc do neutralności jako celu, wstępnie definiuje ja jako takie praktyki czy instytucje, które moga być poparte przez ogół obywateli jako pozostające w zakresie publicznej koncepcji politycznej. Takie określenie neutralności celu nie jest jednak zadowalające, gdyż możliwe sa przynajmniej trzy jego interpretacje. Po pierwsze, może ono oznaczać, iż państwo ma zapewnić wszystkim obywatelom możliwość realizowania każdej uznawanej przez jednostki koncepcji dobra. Po drugie, państwo nie może faworyzować żadnej $z$ doktryn. Po trzecie, państwo nie powinno czynić nic, co czyni bardziej prawdopodobnym, że jednostki przyjmą tę, a nie inną koncepcję, chyba że zrównoważy w jakiśs sposób owe skutki ${ }^{13}$.

Przykładając tak rozumiane pojęcie neutralności do swojej koncepcji pierwszeństwa słuszności, Rawls odrzuca pierwsze $z$ możliwych sformułowań jako $z$ nia niezgodne. Dopuszczalne sa bowiem jedynie te style życia, które przestrzegaja zasad sprawiedliwości. Ten sposób definiowania neutralności (określany niekiedy jako „neutralność szans”) jest w zasadzie sprzeczny z każda interpretacją liberalizmu, która kładzie nacisk na ogólne zasady sprawiedliwości bądź też uprawnień.

Jeżeli chodzi o drugie znaczenie, to wydaje się ono całkowicie spełniać wymagania koncepcji pierwszeństwa słuszności. Państwo, kierując się tą zasada, nie może w żaden sposób promować czy też wspierać którejkolwiek $z$ doktryn.

Co do trzeciego znaczenia, które Rawls ujmuje w kategorie wpływu czy też skutku, to jego zdaniem należy je odrzucić jako niemożliwe do zrealizowania. Rawls, podobnie jak Larmore, wyraża tu przekonanie, iż wymóg neutralności działań państwa co do skutku musiałby nieuchronnie prowadzić do sparaliżowania

12 J. Rawls: Liberalizm polityczny, przekład A Romaniuk, Wydawnictwo Naukowe PWN, Warszawa 1998 , s. 268.

${ }^{13}$ Rozróżnienie to Rawls zaczerpnał z Morality of Freedom Josepha Raza. 
w podejmowaniu decyzji. Watpliwe jest nawet, czy ów wymóg dałby się utrzymać $\mathrm{w}$ państwie minimalnie zaangażowanym - takim, jak chce Robert Nozick. Na ogół zwolennicy neutralności zgodnie odrzucają więc tę interpretację.

Ważne jest podkreślenie, iż mimo uznania neutralności celu państwa, nie musi ono się powstrzymywać, zdaniem Rawlsa, od głoszenia pewnych cnót politycznych, takich jak tolerancja, rozumność czy poczucie sprawiedliwości. Katalog tych cnót opisuje teoria sprawiedliwości. Sa one dopuszczalne jako idee należące do jakiejś rozumnej koncepcji sprawiedliwości (można przyjąć, iż większość obywateli je uznaje, a tym samym sa niezależne od jakiejś rozległej doktryny) i, co najważniejsze, nie prowadzą do perfekcjonizmu państwowego.

Jak widać $z$ przedstawionych wyżej opisów, znaczenia neutralności u Larmore'a i Rawlsa sa blisko spokrewnione, ale oczywiście różnią się między sobą, choć może nie tak dalece, jak to widzi Rawls. Ciekawe rozróżnienie tych koncepcji przedstawił Richard J. Arneson: „Przykładem polityki państwa, która spełnia warunki neutralności procedury, lecz nie neutralności celu, byłoby ustanowienie jakiejś religii religia państwowa nie na gruncie przeświadczenia, iż owa religia jest $z$ natury lepsza od konkurentek, ale $\mathrm{w}$ przekonaniu, iż promowanie jednej religii sprzyja zachowaniu pokoju publicznego. $Z$ kolei przykładem polityki, która spełnia warunki neutralności celu, lecz nie neutralności procedury, byłaby polityka szerokiej tolerancji religijnej uzasadniona na gruncie przekonania, iż religia kwakrów jest jedyną prawdziwą, więc zgodnie $z$ jej zasadami powinna panować szeroka tolerancja religijna, a państwo nie powinno opowiadać się po stronie żadnej religii" ${ }^{14}$. Arneson stoi na stanowisku, że nie ma przeszkód, aby połączyć obie formy neutralności, formułując jedno, bardziej wymagające kryterium.

${ }^{14}$ R. Arneson: Neutrality and Utility, „Canadian Journal of Philosophy” 1990, vol. 20, nr 2, s. 218-219, cyt. za W. Galston: Cele liberalizmu, przekład A Pawelec, Społeczny Instytut Wydawniczy Znak, Kraków 1999, s. 118. 
Przeciwko idei państwa neutralnego występuje wielu filozofów zaliczanych do nurtu komunitarianizmu. Niektórzy z nich nie odżegnuja się od liberalizmu, ale inaczej go postrzegają: jako koncepcje materialnie określona. Tym, co ich łączy, jest przekonanie, iż ideę neutralności należy zastapić koncepcja dobra wspólnego. Takie sformułowanie problemu może być nieco mylące, gdyż polityka liberalnej neutralności też działa na rzecz dobra wspólnego, a mianowicie umożliwia wszystkim obywatelom realizowanie indywidualnych preferencji. Przy czym wszystkie preferencje maja tę samą wagę (oczywiście $z$ zastrzeżeniem, że pozwalaja innym na współistnienie) $\mathrm{w}$ tym sensie, iż nie sa oceniane $z$ publicznego punktu widzenia, a nie dlatego, że nie istnieje jakaś wewnętrzna miara ich wartości ${ }^{15}$. Tymczasem przez zwolenników koncepcji dobra wspólnego rozumiane jest ono jako materialna doktryna dobrego życia. Tak rozumiany wspólnotowy styl życia ma dostarczać kryterium oceny indywidualnych preferencji. Nas nie interesuje jednak tutaj model społeczeństwa i państwa proponowany przez ten nurt filozofii politycznej, lecz argumenty podnoszone przeciwko idei neutralności państwa liberalnego. Uogólniając, można stwierdzić, iż przeciwnicy tej idei przede wszystkim starają się wykazać, że neutralna polityka państwa (jakkolwiek by ja rozumieć) może się przyczyniać do zburzenia fundamentów, na których wspiera się liberalizm, takich jak pluralizm, autonomia jednostki czy samostanowienie.

Przeciwnicy neutralności podnosza, iż nie chroni ona wystarczajaco środowiska społecznego, niezbędnego, ich zdaniem, do samostanowienia jednostki. Sensowny wybór stylu życia wymaga dostępności wielu możliwości wyboru. Tymczasem polityka neutralna będzie prowadzić do eliminacji tych stylów życia, które wymagaja dużego wysiłku, ale sa wartościowe $z$ punktu widzenia całej społeczności. Taka polityka byłaby zatem samobójcza $z$ punktu widze-

\footnotetext{
${ }^{15}$ Por. J. Rawls: Social Unity and Primary Goods, w: A. Sen, B. Williams (red.): Utilitarianism and Beyond, Cambridge University Press, Cambridge 1982, s. 172 za: W. Kymlicka: Wspótczesna filozofia polityczna, przekład A. Pawelec, Społeczny Instytut Wydawniczy Znak, Kraków 1998 , s. 230.
} 
nia tak cenionego przez liberałów pluralizmu. Wydaje się, że w tym rozumowaniu tkwi błąd, spowodowany patrzeniem $z$ perspektywy materialnie określonej koncepcji dobra wspólnego. Krytycy neutralności uznaja, że skoro liberalizm podnosi do rangi wartości pluralizm, to powinien także przedsiębrać środki do jego ochrony (oczywiście, tu widza rolę państwa). $Z$ pewnością nie można się zgodzić $z$ tak przedstawionym rozumowaniem. Rawls uznaje, iż „społeczeństwo dobrze urządzone określa sprawiedliwy kształt drugiego planu, tak aby style życia miały uczciwa szansę przetrwania. Jeśli dana koncepcja dobra nie jest w stanie utrzymać się i zdobywać nowych zwolenników w warunkach równej wolności i wzajemnej tolerancji, to należy zapytać, czy mamy do czynienia $z$ koncepcja zdolna do życia i czy powinniśmy żałować, że skazana jest na wymarcie"16. Założenie, iż w liberalnym społeczeństwie przepadna jedynie koncepcje nie zasługujace na przetrwanie William A. Galston ocenia jako prostoduszne i „niegodne poważnej filozofii społecznej"17. Jednak dla liberałów takich jak Rawls ma ono dużo głębsze uzasadnienie. Aby to dobrze pokazać, należy cofnać się nieco w rozważaniach i poszukać źródeł owego pluralizmu.

Nowoczesne społeczeństwa demokratyczne charakteryzuje rozległy pluralizm doktryn filozoficznych, religijnych i moralnych. Sa to doktryny, których w żaden sposób nie da się ze soba pogodzić. Nie to wydaje się jednak największym problemem, lecz fakt, iż większość $z$ tych doktryn jest rozumna ${ }^{18}$, a mimo to żadna $z$ nich nie zostaje uznana przez ogół społeczeństwa. Dlatego Rawls zostaje zmuszony do uznania faktu rozumnego pluralizmu. Źródeł owego pluralizmu można upatrywać w wielu czynnikach. Na wstępie Liberalizmu politycznego Rawls umieszcza kilka uwag o charakterze historycznym, w celu zilustrowania przebiegu procesów, które

\footnotetext{
${ }_{16}$ J. Rawls: Fairness to Goodness, „Philosophical Review” 1975, nr 84, s. 549, cyt. za W.A. Galston: Cele..., s. 113.

17 W.A. Galston: Cele..., s. 113.

${ }^{18}$ Oczywiście, w społeczeństwie demokratycznym istnieja także doktryny irracjonalne. „W ich przypadku - pisze Rawls - problem polega na tym, by przyznawać im miejsce takie, by nie podważyły jedności i sprawiedliwości społeczeństwa”. J. Rawls: Liberalizm..., s. 8.
} 
przyczyniły się do powstania pluralizmu. Wymienia więc reformację, która doprowadziła do powstania pluralizmu religijnego i położyła kres średniowiecznej zgodzie. Zamiarem Lutra czy Kalwina nie było oczywiście propagowanie wielości poglądów, ale raczej zreformowanie istniejaccej religii. Konsekwencja pluralizmu religijnego stały się inne odmiany pluralizmu. Kolejnym procesem, który stał się podłożem pluralizmu, był rozwój nowoczesnego państwa $z$ jego centralną administracją. Rozwój nowoczesnej nauki - w kierunku wytyczonym przez Kopernika, Keplera, Leibniza i Newtona - ugruntował różnorodność poglądów już nie tylko w sferze religijnej. W bardziej szczegółowych rozważaniach Rawls odwołuje się do wydarzeń historycznych w Stanach Zjednoczonych, między innymi do wojny secesyjnej czy dyskusji nad konstytucja. Oczywiście takie li tylko historyczne uzasadnienie (zwłaszcza że nie jest to opis wyczerpujący) nie jest wystarczające. Sięgając głębiej, należy stwierdzić, iż rozumny pluralizm jest wynikiem korzystania przez wolnych ludzi $z$ daru autonomicznego rozumu, i jako taki zawsze będzie im towarzyszył. Rawls ujmuje takie wyjaśnienie w postaci koncepcji ciężarów sądów, które mają określać sytuacje przyczyniajace się do tego, iż systematycznie pojawia się rozumna niezgoda między osobami rozumnymi. Przy czym należy zaznaczyć, że ciężary te maja wpływ zarówno na praktyczne czy moralne użytkowanie rozumu, jak i na użytkowanie teoretyczne. Rawls wylicza kilka przykładów ciężarów sądów, i nie jest to zapewne wyliczenie kompletne:

- dowody naukowe i empiryczne sa sprzeczne i złożone, ponadto nie ma nadrzędnych kryteriów, ze względu na które można by je oceniać;

- gdyby nawet kryteria takie przyjąć, mogłyby one mieć różna wagę;

- większość pojęć jest nieostra i umożliwia różnorodną interpretację;

- poszczególne osoby maja odmienne doświadczenia, które wywierają wpływ na ocenę; 
- uznawane wartości moga pozostawać w konflikcie i, podobnie jak przy ocenie dowodów naukowych, brakuje wartości nadrzędnej;

- może zachodzić konflikt między uznawanymi wartościami a wydolnościa instytucji społecznych, w wyniku czego będziemy zmuszeni zrezygnować $z$ pewnych wartości.

Rozumni członkowie wolnego społeczeństwa, różniący się między soba pod względem wyznawania rozległych doktryn filozoficznych, moralnych czy religijnych, będą sobie zdawać sprawę, iż wszyscy podlegaja ciężarom sądów. Nie będa się więc domagać, aby zwalczać odmienne doktryny przy użyciu środków represyjnych, gdyż podważałoby to ich status jako jednostek rozumnych. Przy tak postawionym zagadnieniu pytanie, na które musi odpowiedzieć liberalizm polityczny, brzmi: „Jak to jest możliwe, że trwać może stabilne i sprawiedliwe społeczeństwo wolnych i równych obywateli, których głęboko dzielą rozumne, lecz nie dające się pogodzić doktryny religijne, filozoficzne i moralne? Inaczej rzecz ujmując: jak to możliwe, że głęboko przeciwstawne, choć rozumne, rozległe doktryny moga ze sobą współżyć i wszystkie afirmować polityczna koncepcje reżimu konstytucyjnego? Jaka jest struktura i treść koncepcji politycznej, która może uzyskać częściowy konsens?" ${ }^{19}$. Tak więc to nie pluralizm staje się wartościa godna obrony, ale raczej stabilność i pokojowe współistnienie jednostek wyznajacych różne poglądy. Sam pluralizm jest faktem - nieusuwalnym, niejako wpisanym w strukturę człowieka myślącego - i jako taki wymyka się wszelkim ocenom. To, że pewne koncepcje, nawet te wartościowe $^{20}$, nie przetrwaja $\mathrm{w}$ sprawiedliwym spoleczeństwie, nie przesądza o jego braku bezstronności. Państwo nie tylko nie powinno faworyzować żadnego $z$ poglądów, ale także ingerować $w$ żaden inny sposób w „rynek doktryn”. „Można ubolewać - pisze Rawls $-z$ powodu ograniczonej przestrzeni, jaka, można by tak rzec, stwarzaja społeczne światy [...] i możemy ubolewać nad niektóry-

\footnotetext{
19 Ibidem, s. 9.

${ }^{20}$ Rawls wyraźnie odrzuca pogląd, że w sprawiedliwym społeczeństwie przegrywają tylko bezwartościowe formy życia, ibidem, s. 275, przypis.
} 
mi skutkami, jakie nieuchronnie niesie nasza kultura i struktura społeczna. [...] Żadne społeczeństwo nie może jednak zawrzeć w sobie wszystkich form życia" ${ }^{21}$. W podobnym tonie wypowiada się Isaiah Berlin, do którego odwołuje się Rawls. Osią filozofii Berlina jest stwierdzenie, iż $z$ natury świata, wartości i samego człowieka wynika niemożliwość stworzenia odpowiedniej przestrzeni dla wszystkich ${ }^{22}$. Nie ma świata społecznego bez strat i tragedia ludzka jest po części tego odzwierciedleniem. Jednak sprawiedliwe społeczeństwo liberalne zapewnia dużo więcej przestrzeni niż inne społeczne światy.

Kolejny zarzut, nieco zbliżony do poprzedniego, postawiony jest jednak już z pozycji filozofii komunitarian. Podważają oni mianowicie możliwość samorealizacji i budowania własnej tożsamości, a co $z$ tego wynika - wydawania jakichś sąów wartościujących $z$ dala od wspólnych doświadczeń i w sposób pozbawiony publicznej debaty. Poza wspólnota językową i wspólnota zwyczajów człowiek pozostałby jedynie istota biologiczna. Teza o ontologicznej uprzedniości wspólnoty politycznej przed jednostka pochodzi już od Arystotelesa, nie jest więc niczym odkrywczym. Jednak komunitarianie wyciagają $z$ niej istotne konsekwencje. A mianowicie, skoro wspólny język, obyczaje, tradycja (co zbiorczo można określić mianem kultury) stanowia kontekst, bez którego jednostka nie jest w stanie odkryć i wypróbować swoich wartości, to obowiazkiem państwa jest dbanie o utrzymanie kultury jako pewnej całości, a ponadto zapewnienie publicznej debaty nad wymianą doświadczeń i poglądów. Państwo neutralne nie jest w stanie tego zapewnić, gdyż w ten sposób niewątpliwie wspierałoby określony sposób życia.

Zarzut ten wydaje się jednak równie nieuzasadniony jak poprzedni. Po pierwsze, Rawls nigdzie nie odrzuca możliwości ochrony przez państwo podstawowych zrębów kultury. Podobnie jak Ronald Dworkin, który także opowiada się za państwem neutralnym,

\footnotetext{
${ }^{21}$ Ibidem, s. 274.

${ }^{22}$ Tak m.in. w esejach: O dażeniu do ideału. Dwie koncepcje wolności, w: I. Berlin: Dwie koncepcje wolności i inne eseje, przekład H. Bartoszewicz, D. Grinberg, S. Kowalski, M. Tański, Res Publica, Warszawa 1991.
} 
stwierdza jedynie, że hierarchizowanie rozmaitych elementów kultury nie powinno leżeć w gestii państwa. Po drugie, uważa on, że zasady sprawiedliwości jako takie stanowią wystarczająca ochronę i zabezpieczenie kultury. Ponadto $z$ samej konstrukcji koncepcji liberalizmu politycznego wynika, iż niezbędne jest podtrzymywanie przynajmniej tej części wspólnego dziedzictwa, które gwarantuje trwanie społeczeństwa respektującego jej zasady.

Analizując przytoczone wyżej zarzuty, można stwierdzić, iż jedna $z$ przyczyn nieporozumień między zwolennikami neutralności a jej przeciwnikami jest brak odróżniania działań politycznych od wspólnych działań społeczeństwa obywatelskiego. Schodząc na grunt praktyki, absurdem byłoby zapewne utrzymywać, że realne osoby rzeczywiście sa w stanie wybierać styl życia w całkowitej izolacji od wspólnej kultury. To, że człowiek - mówiąc językiem komunitarian - jest zanurzony w społeczeństwie, nie podlega zaprzeczeniu ze strony liberałów (przynajmniej wyżej wspominanych). Oczywiście, dyskusyjna będzie teza o wpływie (a raczej jego stopniu) społeczeństwa na jednostkę i jej możliwość zdystansowania się wobec pewnych koncepcji (za czym opowiada się liberalizm). Niemniej teza liberalizmu, iż poszczególne style życia nie podlegają osądowi publicznemu nie neguje wartości debaty publicznej nad nimi, tyle że państwo, ze stojacym za nim aparatem przymusu, nie jest właściwym forum dla tych rozważań. W dobrze urządzonym społeczeństwie ludzie nie „sięgaja po państwowy aparat przymusu, by zdobyć dla siebie większa swobodę czy większy udział $\mathrm{w}$ dystrybucji $z$ tej racji, że ich działania maja większa wewnętrzną wartość" ${ }^{23}$. Perfekcjonistyczne ideały moga być realizowane $\mathrm{w}$ społeczeństwie obywatelskim, w ramach grup, stowarzyszeń, a nawet rodziny, tyle że uczestnictwo w tych instytucjach jest dobrowolne. Liberalizm nie neguje zatem potrzeb społecznych służących realizacji jednostki jako wolnej i autonomicznej, jednak sięga $\mathrm{w}$ ich rozumieniu do warstwy społecznej właśnie, nie zaś

${ }^{23}$ J. Rawls: Teoria sprawiedliwości, przekład M. Panufnik, J. Pasek, A. Romaniuk, Wydawnictwo Naukowe PWN, Warszawa 1994, s. 451. 
politycznej. Odmienna rola państwa wedle liberałów sprowadza się raczej do funkcji administrujących, jednak zapewnia równocześnie pewne minimum pozwalające na realizowanie swoich potrzeb przez wszystkich członków społeczeństwa. Takie spojrzenie dowodzi bra$\mathrm{ku}$ wiary $\mathrm{w}$ politykę jako narzędzia wypracowywania kontekstu wspólnotowego, pozostawia to $z$ ufnościa samemu społeczeństwu. Państwo liberalne, stojąc na straży wolności słowa i stowarzyszania, zapewnia społeczeństwu miejsce na wolną wymianę myśli.

Paradoksalnie - komunitarianie, wysuwając tezę o konieczności większego zaangażowania państwa i opowiedzenia się po stronie jakiejś koncepcji dobra, wykazują większy brak zaufania do społeczności, niejako zakładając, iż w razie braku właściwej ochrony państwowej tego dobra będzie prowadzić do samozniszczenia. Przekreślaja to, co niekiedy przyjmuje liberalizm, a mianowicie możliwość wspólnotowego podejmowania działań w interesie całego społeczeństwa bez braku przymusu.

Teza społeczna rodzi jeszcze jeden zarzut pod adresem neutralnego państwa. Jakkolwiek by postrzegać rolę państwa, aby dobrze spełniało ono swoją funkcję, musi mieć legitymizację. Tymczasem państwo neutralne, bez wizji dobra wspólnego, legitymizacji mieć nie może, gdyż obywatele nie utożsamiają się z nim. Będzie to prowadzić do takich konsekwencji, że obywatele nie będą skłonni do akceptowania nakładanych na nich obciążeń finansowych związanych na przykład z polityka społeczną.

Tymczasem Rawls, a także Larmore, sądza, iż obywatele będa skłonni akceptować wydatki na wspólna politykę mimo odmienności koncepcji życia, ponieważ będa akceptować podstawowa strukturę państwowa jako nie kolidujaca $z$ ich partykularnymi wartościami. Dla Rawlsa będzie to wynikać z przyjętych publicznie zasad sprawiedliwości, dla Larmore'a zaś $-z$ woli prowadzenia racjonalnego dialogu. „Tłem tej kwestii [legitymizacji władzy - Ż.O.] - pisze Rawls - jest to, że, jak zawsze, uważamy obywateli zarówno za wolnych i równych, jak za rozumnych i racjonalnych, a też traktujemy rozmaitość rozumnych doktryn religijnych, filozoficznych 
i moralnych funkcjonujących w społeczeństwach jako trwała cechę ich publicznej kultury. Uznając to i rozumiejac władze polityczna jako władzę obywateli stanowiących ciało zbiorowe, pytamy: kiedy władza ta jest właściwie sprawowana? To znaczy w świetle jakich zasad czy ideałów musimy umieć, jako wolni i równi obywatele, postrzegać siebie jako sprawujących tę władzę, jeśli to nasze jej sprawowanie ma się uzasadniać wobec innych obywateli i ma polegać na szanowaniu ich rozumności i racjonalności? W odpowiedzi na to liberalizm polityczny mówi: sprawowanie przez nas władzy politycznej jest w pełni właściwe tylko wtedy, gdy sprawujemy ja zgodnie $z$ konstytucja, co do której można rozsądnie oczekiwać, że wszyscy jej obywatele popra jej najważniejsze elementy w świetle zasad czy ideałów, które moga oni przyjąć kierując się wspólnym im ludzkim rozumem. Taka jest liberalna zasada legitymizacji. [...] Tylko taka polityczna koncepcja, co do której można rozsądnie się spodziewać, że popra ją wszyscy obywatele, może służyć jako podstawa publicznego rozumu i uzasadnienia" ${ }^{24}$.

Kwestia legitymizacji władzy politycznej jest dla Rawlsa argumentem przemawiajacym za zasada neutralności państwa a nie przeciwko. Osobom o różnych koncepcjach dobra trudno będzie zaakceptować politykę oparta na obcej im koncepcji. Dlatego też państwo neutralne, kierujące się zasadami abstrahującymi od poszczególnych koncepcji dobra, ma o wiele większe szanse na akceptację. Podobnie argumentuje na rzecz neutralności prawa wobec różnych systemów etycznych Sadurski ${ }^{25}$ podnosząc, iż w kwestii źródła obowiąku przestrzegania prawa (nie prawnego oczywiście, lecz raczej moralnego) neutralność prawodawcy może mieć kluczowe (choć niekoniecznie wystarczające) znaczenie. Respektowanie prawa ustanowionego przez neutralnego prawodawcę, nie faworyzującego żadnego $z$ konkurujących ze sobą systemów moralnych $\mathrm{w}$ pluralistycznym systemie, powinno być większe.

J. Rawls: Liberalizm..., s. 198-199.

${ }^{25}$ W. Sadurski: Neutralność..., s. 34-35. 
Na koniec przytocze jeszcze jeden zarzut przeciwników neutralności, majacy charakter fundamentalny. Chodzi o stwierdzenie, iż neutralność państwa jako taka jest $z$ natury rzeczy niemożliwa: „Nie musimy jednak odwoływać się do pośrednich efektów społecznej różnorodności - pisze Galston - aby zanegować pełną neutralność państwa liberalnego. Istnieje szerokie spektrum kontrowersyjnych kwestii, co do których - jak nakazuje logika i praktyka - spierajace się strony nie moga po prostu pozostać przy swoim zdaniu i muszą dojść do wiążacych ustaleń. Niezależnie od ostatecznej decyzji wspólnota polityczna opiera się na określonej wizji ludzkiej osobowości i słusznego postępowania, a także wpływa na inne instytucje i praktyki. W takich przypadkach neutralność nie jest pogwałcona, albowiem nigdy nie jest możliwa Każde państwo ucieleśnia zatem ponadminimalna koncepcję dobra, która przynajmniej częściowo szereguje indywidualne style życia i konkurencyjne zasady słusznego postępowania" ${ }^{26}$.

Zarzut ten ma właściwie dwa wymiary: teoretyczny oraz praktyczny. Odwracając kolejność, zacznę od zarzutu natury praktycznej.

Przeciwnicy neutralności podkreślaja, iż żadne państwo nie może być neutralne, gdyż każda decyzja wywołuje skutki, które niewątpliwie różnicuja $\mathrm{w}$ społeczeństwie pozycje osób wyznających odmienne koncepcje życia. Chodzi więc tutaj o jeden ze wspomnianych wcześniej aspektów neutralności, a mianowicie neutralność skutków. Zarówno Rawls, jak i Larmore odrzucaja jednak tak rozumianą neutralność, jako w istocie niemożliwą do spełnienia. Nawet gdyby teoretycznie było to możliwe, i tak byłoby sprzeczne $z$ całościa doktryny liberalnej, gdyż w istocie musiałoby prowadzić do państwa silnie zaangażowanego.

Jeśli chodzi o drugi aspekt, to przeciwnicy neutralności twier$\mathrm{dza}$, iż liberalne państwo nie jest w istocie neutralne, gdyż uznaje pewien ideał życia, mianowicie taki, który afirmuje wolność, tolerancję, pluralizm. U podstaw takiego systemu leżą więc otwarcie lub milcząco zakładane pewne wartości. W istocie jednak żaden

${ }^{26}$ W. Galston: Cele..., s. 114. 
zwolennik (przynajmniej rozsądny) tej zasady nie utrzymuje, że sama neutralność państwa ma uzasadnienie neutralne. Stanowi bowiem pewna interpretacje „określonego ideału, który nie jest ani neutralny, ani oczywisty, ani nawet niekontrowersyjny”27. Państwo liberalne musi jednak zachowywać neutralność wobec koncepcji dobrego życia (wedle Larmore'a nawet nie wobec wszystkich), ale jednocześnie musi respektować te, które sa publicznie dyskutowane w społeczeństwie ${ }^{28}$. Dla Rawlsa przesłanki te zostana spełnione wówczas, gdy decyzje będą neutralne pod względem celu, w jakim były podjęte, dla Larmore'a zaś - gdy decyzje zostana podjęte $z$ uznaniem reguł racjonalnego dialogu. Przyjęcie pewnych zasad - takich jak wolność jednostki w obszarze nie wkraczającym na obszar wolności innych czy też swoboda decydowania o sposobie życia, nawet gdyby to życie miało być szkodliwe $z$ punktu widzenia większości - nie prowadzi do perfekcjonistycznego państwa rozległej doktryny.

Zarówno Rawls, jak i Larmore postrzegaja siebie jako przedstawicieli liberalizmu politycznego. Liberalizm ten nie ma zaś być jakąś kolejna rozległa doktryna, ale raczej godzić istnienie w pluralistycznym społeczeństwie rozległych doktryn, nie dających się ze sobą uzgodnić. Wydaje się, że całkowicie neutralne państwo nie byłoby w stanie funkcjonować, gdyż podjęcie jakiejkolwiek decyzji wymaga ustalenia priorytetów. Jak jednak pokazałam, sam ten fakt nie przekreśla jego neutralności.

Tak przedstawiony liberalizm polityczny $z$ jego interpretacja neutralności państwa nie jest być może koncepcją doskonała, jednak uwzględniając realia współczesnych społeczeństw, stara się szukać rozwiazań pozwalających wszystkim na pokojowa koegzystencję. Wydaje się, że jest doktryną najpojemniejszą, choć zapewne nie jest w stanie ochronić wszystkich. Powtarzając za Berlinem: świat społeczny nie może być bez strat, ale świat liberalny zapewni dużo więcej przestrzeni niż inne światy społeczne.

${ }^{27}$ W. Sadurski: Neutralność..., s. 28.

${ }^{28}$ Ch.E. Larmore: Patterns..., s. 67. 